\title{
Research on the Impact of Financial Services on County Economic Development
}

\author{
Yan Lv ${ }^{1}$, Tong Ouyang ${ }^{1}$, Xiao Chen ${ }^{1}$, Ziyue Zhang', Chaolin Li ${ }^{2}$, * \\ ${ }^{1}$ School of Finance, Anhui University of Finance and Economics, Bengbu, Anhui, China \\ ${ }^{2}$ School of Economics, Anhui University of Finance and Economics, Bengbu, Anhui, China \\ ${ }^{*}$ Corresponding author email: 952587990@qq.com
}

\begin{abstract}
In recent years, China's finance has become an important factor affecting the development of county economy. Taking Qianshan city of Anhui Province as an example, this paper studies the role of county finance in the development of county economy. Firstly, combining the theory and practice of the impact of financial development on economic development put forward by scholars, this paper discusses the practical significance of these theories in China's counties in the 21st century. Secondly, it mainly compares the economic and financial development of Qianshan city with the economic and financial development of surrounding brother counties, draws a conclusion, and analyzes the transmission path of county financial services affecting county economic development. Finally, based on the above research results, the specific conclusions of the impact of county finance on county economy are obtained, and the corresponding policy suggestions are given according to the current research results.
\end{abstract}

Keywords: County economy, Financial services, Financial development theory.

\section{Introduction}

At present, the total area of counties accounts for $93 \%$ of China's total land area, the county population accounts for about $74 \%$ of the country's total population, and the county GDP accounts for about $56 \%$ of the country's total GDP at the peak of this century. It can be said that the county economy is China's people's livelihood economy, national economy, the most basic ecological economy and stable economy. At the same time, the county is the spatial carrier of China's agricultural development. Promoting Rural Revitalization and solving the "three rural" problems are the major responsibility of the county economy. Although the county economy should compete and develop in a competitive environment, and the competitive advantage is the characteristic economy, the county economy is not a competitive economy and cannot take the level of GDP as the evaluation standard [1].

County finance refers to the general term for financial institutions to carry out financial intermediary services and provide financing activities in the geographical space of county-level administrative divisions. In reality, the country has basically achieved full coverage of basic financial services in villages and towns, and Inclusive Finance has gradually spread to county and rural areas. However, there are still many factors restricting the development of county finance. The first is the system problem, which includes not only the composition of county financial institutions, but also the operation of financial institutions. The second is the problem of innovation. Financial institutions lack innovation in financial services. The third is the risk problem. Due to the low level of economic development and lack of credit awareness, the risk faced by county financial institutions is higher than that in first tier cities. Fourth is the information problem. There is serious information asymmetry in the process of county economic development, which is embodied in the information asymmetry between financial institutions and the government and between financial institutions and enterprises [2].

At present, the financial development of Qianshan city in Anhui Province is not optimistic, which is reflected in the relatively low deposit and loan, the insufficient liquidity released, the imperfect financial system, the excessive proportion of banking financial institutions, the common phenomenon of only deposit and no loan, and so on. Aiming at the economic development of Qianshan city and the development of county finance, this paper mainly puts forward three questions: what is the current economic development of Qianshan city and the development of county finance? How does county financial development affect county economy? How to develop county finance in the new era? These three problems will be discussed in the next research.

\section{Economic and Financial Development status of Qianshan City}

\subsection{Economic Development}

In 2019, Qianshan city achieved a regional GDP of 20.787 billion yuan, an increase of $8.5 \%$ over the previous year at comparable prices. Among them, the added value of the primary industry was 2.636 billion yuan, an increase of $2.8 \%$. The added value of the secondary industry was 9.313 billion yuan, an increase of $11.4 \%$; The added value of the tertiary industry was 8.837 billion yuan, an increase of $7.1 \%$. The ratio of tertiary industrial structure was adjusted to 12.7 : 44.8: 42.5. The contribution rates of primary, secondary and tertiary industries to economic growth were $4.8 \%, 63.2 \%$ and $32.0 \%$ respectively. According to the resident population, the per capita regional GDP is 39936 yuan. In 2019, Qianshan city completed a public budget revenue of 1442.49 million yuan, an increase of $10.3 \%$ over the previous year. Among them, the local fiscal revenue was 906.2 million yuan, an increase of $6.0 \%$. From the perspective of the composition of local fiscal revenue, the tax revenue was 609.79 million yuan, a year-on- 
year increase of $8.9 \%$. In terms of local tax categories, the value-added tax was 334.88 million yuan, a year-on-year increase of $18.2 \%$. Corporate income tax reached 27.61 million yuan, an increase of $57.2 \%$. Fiscal revenue accounted for $6.94 \%$ of GDP.

\subsection{Investment and Financing}

The annual investment in fixed assets increased by $12.4 \%$ over the previous year, including: industrial investment increased by $2.2 \%$. The investment in projects above 50 million yuan increased by $5.6 \%$. Among them, investment in technological transformation increased by $15.0 \%$; Private investment increased by $0.7 \%$ year-on-year, accounting for $66.1 \%$ of all investment. The annual investment in real estate development was 141.355 million yuan, an increase of $15.1 \%$ over the previous year. At the end of the year, the balance of various deposits in financial institutions was 29377.24 million yuan, a year-on-year increase of $11.7 \%$; Among them, the balance of savings deposits of urban and rural residents was 20014.69 million yuan, a year-on-year increase of $10.5 \%$. At the end of the year, the loan balance of financial institutions was 13981.58 million yuan, an increase of $17.2 \%$.

\subsection{Impact of Financial Services on County Economic Development}

Here, the total GDP of Qianshan city in 2019 and the deposits and loans of financial institutions at the end of the year are selected to explore the relationship between economic development and the amount of deposits and loans. In 2019, the total GDP of Qianshan city was 20.787 billion yuan, with a year-on-year increase of $8.5 \%$ and per capita GDP of $4.5 \% 0.01$ million yuan, and the balance of various deposits of financial institutions at the end of the year was 29377.24 million yuan. Including the balance of savings deposits of urban and rural residents is 20 billion yuan. At the end of the year, the loan balance of financial institutions was 13981.58 million yuan. From the perspective that banks want to make profits, banks prefer to see a higher deposit loan ratio, because deposits pay interest to depositors, while loans can receive interest from debtors. The current deposit loan ratio of Qianshan city is 0.470 , which is lower than that of the brother counties, which indicates that there is still a considerable amount of liquidity in Qianshan City, and the support of financial institutions to the real economy is not enough. The next step in the development of financial services in Qianshan city should appropriately relax loan restrictions and release excess liquidity.

\section{Theoretical Analysis of the Impact of Financial Services on County Economic Development}

\subsection{Theoretical Analysis of Financial Development}

\subsubsection{Financial repression theory}

Ronald I. McKinnon and Shaw demonstrated the dialectical relationship between financial development and economic development. They put forward financial repression according to the actual situation of developing countries. Financial repression means that most developing countries generally control and intervene in interest rates and exchange rates in order to support rapid economic development. For financial intermediaries, the government often manipulates their business activities by means of administrative command, which often leads to the negative effect of low efficiency of financial intermediaries. Financial repression in developing countries is mainly reflected in the following aspects: artificially lowering real interest rates. Allocate credit funds by means of credit rationing. The government adopts the credit rationing policy and invests funds into limited enterprises, most of which are privileged state-owned enterprises, and the investment income is generally not ideal, which leads to the low efficiency of fund distribution. Implement strict control over financial institutions, including requiring high legal reserve ratio and liquidity for financial institutions, strictly restricting the development of certain types of financial institutions, nationalization of financial institutions, etc. Artificially overestimate the exchange rate of local currency [3]. In the process of the great development of county economy in China there are also some phenomena of financial repression. County Financial Institutions in China are relatively single, mostly state supported banking financial institutions, which not only lack the participation of other financial institutions, but also are unevenly distributed, and the construction of financial institutions in villages and towns in remote areas is missing. Moreover, the government has restricted the loan authority of financial institutions. Except that rural credit cooperatives have complete loan authority, the loan authority of other financial institutions has been more or less restricted, which leads to the phenomenon of more deposits and less loans in the county economy. Ordinary people who want to invest lack investment channels, and it is difficult for enterprises who want to finance to obtain loans [4].

In February 2020, the RMB deposit balance of financial institutions in Qianshan City reached 30.026 billion yuan, a year-on-year increase of $6.1 \%$, of which the household deposit balance was 22.297 billion yuan, an increase of $8.1 \%$. The balance of loans was 14.111 billion yuan, an increase of $14.2 \%$. The deposit loan ratio has reached 0.470 . In this case, a considerable part of the capital flow has stagnated. Financial institutions not only can not get income from it, but also pay interest, and enterprises have no channels to finance. In this case, financial institutions can not promote economic development, but play a negative role in economic development, and lead to the rise of informal lending institutions.

\subsubsection{Financial Deepening Theory}

The theory of financial deepening holds that developing countries must carry out financial liberalization reform. The core content of financial liberalization reform mainly includes the following aspects: deregulation of interest rate. Reduce the use of guidance credit plans. Reduce restrictions on the examination and approval of financial institutions and promote horizontal competition. Issue direct financing instruments, increase the number of tradable financial instruments, and cultivate the primary and secondary securities markets. Relax restrictions on exchange rates and capital flows. The theory of financial deepening was tested by Argentina, Chile, Uruguay and other countries in the 1970s, and achieved certain results. However, financial liberalization also leads to financial fragility, so the adoption of financial deepening also needs to be determined according to the current macroeconomic situation. In the development of county economy in China, there are some financial inhibition phenomena. Therefore, some financial liberalization policies can effectively deal with some problems in the development 
of county economy. China's interest rate liberalization is still advancing steadily. The newly launched LPR is undoubtedly an important step in relaxing interest rate control. The science and Innovation Board officially opened in Shanghai Stock Exchange also plays a great role in activating the securities market [5]. China's attitude towards financial liberalization should be to steadily advance according to the macroeconomic situation and cooperate with the price reform or free pricing mechanism. We should not superstitious about financial deepening, face up to the risks brought by financial deepening and combine the functions of the government and the market.

\subsubsection{Financial Constraint Theory}

In the view of traditional economics that attaches importance to market mechanism, financial repression should have a serious reaction to economic development, but in fact, some of the situations are just the opposite. For example, Thailand and Indonesia in Southeast Asia have more or less financial repression, but the economic development speed of these countries after World War II is shocking, which challenges the financial repression theory and urges economists to further improve the financial development theory [6]. On this basis, Hellman, Murdock and Stiglitz (1997) in financial constraints: a new analytical framework This paper puts forward the theoretical analysis framework of financial constraints. On the surface, financial constraints are the opposite of financial liberalization. Financial liberalization emphasizes the role of market mechanism in economic operation, while financial constraints pay attention to the participation of government departments in economic operation. But in fact, financial restraint is the further development of the theory of financial deepening. It focuses on the market manipulation and information asymmetry in the process of economic development in developing countries, and emphasizes the role of the government in combating monopoly, which makes the market operation tend to be normalized. Therefore, financial restraint and financial deepening are inseparable.

On the whole, the preconditions of the theory of financial constraints are too strict, and "deify" the role of the government. If the development of an industry can be promoted only through the policy support of the government, the economic operation is a little too simple. Therefore, the specific implementation of financial restraint theory in China is almost impossible, but some of its ideas are worth learning. At present, the county financial market is indeed full of chaos. Informal private lending institutions are springing up, and all kinds of loans emerge one after another. However, county financial institutions are slow in lending, have many lending procedures, and have a lot of loans. In the face of the competition of private financial institutions, they lack advantages. The government can play a certain role by cracking down on informal lending institutions, so as to strengthen the control of formal financial institutions over the economy, so as to correctly guide the development of the economy.

\subsection{Theoretical Analysis on the Relationship Between County Financial Development and County Economic Development}

\subsubsection{Theoretical Analysis of Demand Following Finance}

Demand following finance believes that the county economy is the basis of county financial development. The development of county economy needs the progress of county finance to provide funds and service support. Therefore, the development of county economy is ahead, the development of financial services is behind, and the development of economy leads the development of financial services. On the whole, the development of demand following finance is suitable for the development of county economy itself. In this era, as long as financial institutions do their part and provide sufficient funds and financial services for the development of county economy [7]. The profit seeking nature of financial institutions will urge them to strengthen the construction of financial services in the county to obtain more profits. The state will also issue more money in due time to meet the needs of economic development for more money. However, in the era of slow development of county economy, the demand following financial theory is no longer suitable for the needs of economic development.

The county economy develops slowly, the demand for financial services and money is insufficient, the development of financial institutions in the county also tends to stagnate, and the issuance of loans is also insufficient. The slow development of county economy delays the development of financial institutions, and the inaction of financial institutions makes the development of county economy powerless, so it falls into a vicious circle.

For the current situation of China's county economy, I think the demand following financial theory is difficult to play a role. Because the development of most county economies in China does not have the prerequisite of demand following finance, that is, stable and healthy economic development. County economic transformation has always been a problem perplexing most counties. Under the condition that the pulling force of traditional industries is obviously insufficient, the GDP growth rate decreases year by year. The development of emerging industries has become a consensus of most counties. However, the development of emerging industries undoubtedly requires a lot of financial support, but according to the demand following theory, financial services only provide funds matching the degree of industrial development, which greatly delays the development of emerging industries to some extent. Taking Qianshan City, Anhui Province as an example, the ratio of three industrial structures in 2019 is adjusted to $12.7: 44.8: 42.5$; The contribution rates of primary, secondary and tertiary industries to economic growth were $4.8 \%, 63.2 \%$ and $32.0 \%$ respectively. In the case that the secondary industry still occupies the main force of economic development, although the structure ratio of the tertiary industry is no less than that of the secondary industry, it is insufficient to obtain financial support and has a low pulling effect on the economy.

\subsubsection{Theoretical Analysis of Supply Leading Finance}

Supply leading finance believes that the development of county finance leads the growth of county economy, and the development of county finance can have an active impact on the development of county economy. In the age of slow development of county economy when demand driven finance is difficult to play a role, supply driven finance can play a certain role in promoting the development of county economy. However, the implementation of supply leading finance requires more attention, and puts forward more requirements for government policies and financial institutions and enterprises. Supply leading finance, specifically in the capital supply and financial services, and the capital supply is determined by two aspects: one is the 
country and the other is financial institutions. In order to achieve supply leading finance, the state must appropriately issue more money and increase the issuance of base money. It can create several times of money through money multiplier, which puts forward strict requirements on the amount of money issuance. If the state cannot grasp the degree of additional currency issuance, excessive additional currency issuance will not only cause inflation, but also reduce the real value of wealth in the hands of the people. The requirements put forward by financial institutions are the requirements for the loan object.

The profit seeking nature of financial institutions will make them issue loans to objects who can bear higher interest rates after assessing the risk, so as to obtain higher profits. However, if the object of issuing loans is not the real economy, or the real enterprises with weak value creation ability, it is likely to lead to the prevalence of the trend of "de reality to virtual" and the increase of non-performing loans, so as to combat the development of the real economy. The supply leading economy has higher requirements for enterprises, because the supply leading finance is based on the potential but insufficient funds of enterprises, and then through the advanced capital supply, promote the rapid growth of enterprises and finally drive the development of economy. However, if the enterprise lacks the ability to create leading products, excessive capital supply is likely to lead to the repeated production of a single product. Although it seems that GDP has increased, the products are overstocked in the warehouse and can not be sold, which is not conducive to the sound development of the economy.

According to the current situation of county economy in China, the implementation of supply leading finance may be a good choice to drive the development of emerging industries with sufficient funds and promote the transformation and development of county economy. But there are also risks that go too far. The state and financial institutions should master a "degree" in order to better promote economic development. Both supply leading financial theory and demand pulling financial theory are the products of the last century. If they are to be applied to today's county economic development, they need to be combined with today's actual economic development and avoid copying. Moreover, supply leading finance and demand driven finance complement each other, which are suitable for the development of county economy in different periods. In practical application, we should change flexibly and act according to circumstances.

\section{The Path of Financial Services Affecting County Economy}

\subsection{Financial Services Affect Financing Costs}

An important role of financial institutions is to match the suppliers and demanders of funds in society, so that funds can be guided to the right path. However, due to the insufficient construction of county financial institutions, it is difficult to play this function. The supplier of funds is difficult to find effective investment opportunities, while the demander of funds develops slowly due to the lack of capital supply. If it is difficult for fund demanders to obtain funds from formal financial institutions, they have to turn to private lending institutions. Although private lending institutions lend fast and have a high amount, they also have many disadvantages: loan requirements are strict, and enterprises who want to lend have to mortgage important means of production to lending institutions. Once they fail to repay the principal and interest in time. The means of production are directly owned by the lender, and the original value of such means of production is even higher than the total principal and interest of the loan. The interest rate is high. The interest rate of private lending institutions is generally higher than that of bank loans. The interest rate of "usury" is even more than ten times that of ordinary bank loans. The longer the loan term is, the more difficult it is to repay the interest. In this case, the financing cost is greatly increased, and the enterprises that need funds are facing the dilemma of either stagnant development or paying high interest. Once the development of enterprises is not smooth, it is difficult to promote the development of county economy.

\subsection{Financial Services Affect Investment}

Now another problem faced by county financial institutions is that they can provide too few financial products, which does not meet the investment needs of county economies. Today, with the development of county economy, the wealth of people and enterprises has been expanded, and their requirements for investment are increasing day by day. However, financial institutions provide less financial products, which makes it difficult for county economies to find suitable financial products to invest, so they have to choose to deposit idle funds in banks or store them. The funds deposited in the bank can obtain less income, which is not conducive to the increase of wealth, and the bank's utilization efficiency of deposits is not high, which plays a small role in economic development. Hoarding money is tantamount to a loss, and the funds withdrawn from the flow will not promote the economy.

\subsection{Financial Services Affect Innovation Capability}

The normal financial market can promote the rational allocation of resources and realize the survival of the fittest with the market mechanism. The remaining enterprises are those with great development potential and innovation ability, and the enterprises that are complacent will be gradually eliminated by the market. The current county financial market is difficult to achieve this effect. County financial institutions do not grant loans according to the future development potential and innovation ability of enterprises, but pay more attention to the past performance and background of enterprises. Large companies and state-owned enterprises can obtain loan support more easily, while small and mediumsized enterprises suffer from lack of financial support. In this case, it is very easy to breed inertia and corruption of large enterprises. Once they go bankrupt, the impact on the economy and people's lives will be huge. The economic growth rate will decline sharply and the unemployment rate will soar. Therefore, the government and financial institutions will not want them to go bankrupt. In order to maintain this "big but not collapsed" situation, the strategies that financial institutions can adopt are extremely limited, and the loans to pioneering small and medium-sized enterprises are also limited. Small and medium-sized enterprises with innovative spirit can not get funds, so it is difficult to develop, while large enterprises that can easily get financial support are lazy to develop, which is not only a great blow to the innovative spirit of society, but also not conducive to economic development. After all, the development of large and small enterprises is basically stagnant. Moreover, innovation is the first driving 
force of economic development. The lack of innovation ability also lacks the follow-up driving force of economic development.

\subsection{Financial Services Impact Information Collection}

Information asymmetry has always been a difficult problem for investors and financiers in the financial market. Information asymmetry will lead to adverse selection and moral hazard. Adverse selection refers to that before the transaction, one party has more information than the other party, and the convenience with information advantage tends to conduct the transaction and use the excess information to make profits for themselves. For example, in the loan, the more the enterprises that are about to close down can obtain the loan, they can hide the financial information loan and accept the high interest rate proposed by the bank, because they are doomed to be unable to pay back, No matter how high the interest rate is. Moral hazard is that after accepting the loan, due to information asymmetry, it is difficult for banks to supervise what enterprises do with the loan. In the county economy, enterprises and financial institutions have been in information isolation. Enterprises do not know the transaction expectations of banks, and banks do not know the financial and operating conditions of enterprises. In this way, the first transaction between the two sides will face great risks. If the two sides do not conduct transactions all the time, the deeper the estrangement, the more difficult it will be to break through. If we finally fall into the dilemma of "lemon market", it will be a loss for enterprises and banks. The imperfection of financial services makes both sides fall into the dilemma of insufficient information, which makes it difficult to invest funds in enterprises with high production efficiency. Banks lose interest. Enterprises can only rely on endogenous financing, lose development time, and finally affect the development of county economy.

\subsection{Financial Services Affect Risk Resistance}

The anti risk ability of financial institutions depends in part on its deposit and loan quantity and deposit loan ratio. The more deposits, the lower the deposit loan ratio, the stronger the anti risk ability of financial institutions. The anti risk ability of an enterprise depends on its financing ability and its retained funds. Financial institutions encounter non systemic risks. If they have a complete financial service system, they can borrow from other financial institutions to tide over the difficulties, or several financial institutions jointly agree that in case of crisis, other institutions can help them tide over the difficulties. If they are banking financial institutions, they can also apply to the central bank for assistance. When an enterprise encounters non systemic risks, if it has a complete financial service system, it can apply to financial institutions for loans to tide over the crisis, or sign an agreement with financial institutions before the crisis, agreeing to help the enterprise in case of crisis. A sound financial service system can significantly improve the anti risk ability of financial institutions and enterprises, and only enterprises that have carried the risk can always exert a driving force on economic development.

\section{Policy Recommendations}

\subsection{Strengthening the Construction of County Financial Institutions}

To solve this problem, we can't just rely on national policies and instructions to set hard indicators for financial institutions, which can only solve the symptoms rather than the root causes. We should strengthen the attraction of the county to them and make them willing to set up branches in the county. This requires the joint efforts of the county and financial institutions. The county government should introduce preferential policies for financial institutions, such as tax reduction and providing appropriate venues. Financial institutions should also shift their attention from big cities to small cities at the county level, set up more branches, spread nets and catch more, and make more money. On the contrary, small towns at the county level have become fertile ground for the rapid growth of financial institutions. The joint efforts of the two will provide financial support for the development of county economy, and the development of county economy will also feed financial institutions, mutual benefit and harmonious coexistence.

\subsection{Financial Institutions Should Pay Attention to Small and Micro Loans}

For the main body of county economy, such as farmers and small enterprises, launch financial products with short time limit and small amount. The per capita GDP of the county economy is less than that of big cities, and the main body of the county economy is relatively scattered. Therefore, the demand for large loans is not high, but a large number of small loans are needed. Therefore, the microfinance products of financial institutions can gather idle social funds, add up, and invest this fund in the development of county economy. In this way, people will be more willing to deposit and loan in financial institutions, forming a virtuous circle, which not only accelerates the development of county economy, but also helps financial institutions expand their business.

\subsection{Enhance Innovation Awareness}

Launch a variety of financial derivatives suitable for county economic entities. There are various types of county economic entities, including ordinary farmers who need small loans, small and medium-sized enterprises who need medium loans, and ordinary people who are interested in financial products. These people have different requirements for financial derivatives, and it is difficult to meet their requirements with the existing financial derivatives. Therefore, it is urgent for financial institutions to cultivate innovative spirit and launch various new financial products and their derivative financial products suitable for county economic development.

\subsection{The Government Strengthened Its Supervision Over the Financial Market}

While deregulating the financial market, we should strengthen the supervision of the financial market. Financial deepening will also bring financial fragility. The county government should always maintain close supervision over the county financial market, even if it cuts off bad signs, so as to promote financial institutions to contribute to economic development in a reasonable way. 


\section{References}

[1] Yan Enhu. On the current orientation of county economic development in China [J]. Development research, 2019 (11): 77-82.

[2] Liu Hao, Yin Jinxiao. Difficulties and strategies of financial support for county economy to integrate into the new development pattern -- a field survey from joint-stock banks in the Yangtze River Delta [J]. Economic research reference, 2021(08):55-66.

[3] Ji Lijuan. Problems and policy suggestions on the development of digital Inclusive Finance in rural China [J]. Southwest finance, 2021 (11): 53-64.

[4] Zhang Longyao, Xing Chaohui. Research on the distribution dynamics, regional differences and convergence of digital
Inclusive Finance in rural China [J]. Research on quantitative economy and technical economy, 2021, 38 (03): 23-42.

[5] Pang Bo. On China's high monetization rate from the perspective of financial deepening theory $[\mathrm{J}]$. Financial economy, 2020 (01): 21-28.

[6] Liang pinghan, Jiang Hongze. Financial availability and Internet financial risk prevention -- An Empirical Analysis Based on online MLM cases [J]. China's industrial economy, 2020(04):116-134.

[7] Zhu Wensheng. Research on market-oriented allocation of financial factors in economically underdeveloped areas -- a case study of Huanggang City [J]. Financial education research, 2021, 34(04):62-67. 